\title{
Characterization of substrates of growing media by Fourier transform infrared (FT-IR) spectroscopy for containerized crop production
}

\author{
N. Elakiya* \\ Department of Soil Science and Agricultural Chemistry, Anbil Dharmalingam Agricultural \\ College and Research Institute, Trichy - 620027 (Tamil Nadu), India

\section{K. Arulmozhiselvan} \\ Centre of Excellence in Sustaining Soil Health, Anbil Dharmalingam Agricultural College and \\ Research Institute, Trichy - 620027 (Tamil Nadu), India \\ *Corresponding author. Email: elakiya.nandu@gmail.com
}

\section{Article Info}

https://doi.org/10.31018/ jans.v13iSI.2774 Received: March 22, 2021 Revised: April 17, 2021 Accepted: May 8, 2021

\section{How to Cite}

Elakiya, N. and Arulmozhiselvan, K. (2021). Characterization of substrates of growing media by Fourier transform infrared (FT-IR) spectroscopy for containerized crop production. Journal of Applied and Natural Science, 13 (SI), 35 - 42. https:// doi.org/10.31018/jans.v13iSI.2774

\begin{abstract}
Growing media used in soilless culture systems are those solid substrates, which alone or in mixtures can guarantee better plant growth conditions similar to agricultural soil in one or many aspects. This study was aimed to characterize lignocellulosic organic substances predominant in most available and effective organic substrates viz., coir pith and dhaincha (Sesbania aculeata) powder and compost maturity in vermicompost based on the presence of functional groups by Fourier transform infrared (FTIR) spectroscopy. The dominant downward peaks noted at $3300-3500 \mathrm{~cm}^{-1}$ in coir pith and dhaincha indicate vibration of hydroxyl $\left(\mathrm{OH}^{-}\right)$stretch in cellulose structure and presence of alcohols and phenols. Peaks at $2925-2850 \mathrm{~cm}^{-1}$ found prominently in coirpith would be indicative of vibration of $\mathrm{C}-\mathrm{H}$ bonds showing aliphatic degradation of cellulose, hemicelluloses, lipids, fats, etc. Particularly in dhaincha, vibration at $1733.32 \mathrm{~cm}^{-1}$ would be due to $\mathrm{C}=\mathrm{O}$ stretch associated with an unconjugated ketone, carbonyl and ester groups. In vermicompost, peak value around $1549.85 \mathrm{~cm}^{-1}$ indicates $\mathrm{C}=\mathrm{C}$ aromatic structure formed during mineralization of protein, cellulose, and hemicelluloses showing compost maturity. In the present study, FT-IR analysis of organic lignocellulosic substrates confirmed the occurrence of lignin, hemicellulose and cellulose, which are the main characteristics of natural fibers with high water holding and cation exchange capacity. Presence of alcoholic and carboxylic groups indicated stages of compost maturity and stability. Therefore, these renewable and environmentally sustainable lignocellulosic organic materials could be recognized as ideal soilless substrates for preparing grow media for containerized crop production and also recycling organic wastes in an environmentally friendly manner.
\end{abstract}

Keywords: Coir pith, Dhaincha, FT-IR, Growing media, Vermicompost

\section{INTRODUCTION}

Soilless culture systems are increasingly being adopted as a major technological component in the modern greenhouse industry which developed rapidly during the last 30-40 years (Gruda et al., 2018) to sustain profitable agriculture globally over recent decades (Schmilewski, 2009). The term "soilless culture" in general refers to any method of growing plants without the use of soil as a rooting medium (Savvas, 2003; Gruda et al., 2016a). The soilless culture can be done by cultivation of crops on porous growing media which creates a matrix retaining both air and water at suitable ratios for plant growth. The main innovations that turned soilless culture into the leading cultivation technology in modern greenhouses include the development of suitable growing media (GM) with optimal physical, hydraulic, and chemical properties, such as rockwool and coir, and the advances put forth in plant nutrition and irrigation via modern fertigation equipment and automation technologies (Savvas and Gruda, 2018).

Growing media are solid substrates, which alone or in mixtures can guarantee better plant growth conditions similar to agricultural soil in one or many aspects (Gruda et al., 2013). The independence from the soil as a rooting medium in soilless culture facilitates optimizing both physical and chemical characteristics in the crop root environment and more efficient pathogen control eliminating application of soil fumigation. Therefore, higher yields at a reasonable production cost with minimal use of pesticides 
and high product quality can be attained (Gruda et al., 2018).

The selection of an appropriate substrate composition based on technical and economic feasibility is an important aspect of research and key to success in any soilless production system (Vaughn et al., 2011). The growbag media composition may possibly be either inorganic (e.g. perlite, rockwool, vermiculite, gravel, sand, pumice, zeolite, tuff, volcanic porous rock, and expanded clay granules, etc.) or organic in nature (Papadopoulos et al., 2008; Gruda et al., 2016b). Currently, organic materials would meet the requirement of being environment-friendly in the commercial sector (Gruda, 2012; Barrett et al., 2016) and have become the focus of most intensive research attributed to their widespread availability, low cost, easy disposal, renewable and eco-friendly nature (Raviv, 2013; Gruda et al., 2018). As the importance of soilless culture is likely to rise in the near future, it is essential to take research work towards identifying new materials that are environmentally sustainable, commercially viable and able to perform as well as those they are replacing (Barret et al., 2016).

Nowadays, the most available and effective organic substrates are coir pith, vermicompost, peat, etc. Coir is a $100 \%$ organic naturally occurring fiber derived from a renewable resource of coconut husk. Raw coir pith consists of 35 per cent cellulose, 25.2 per cent lignin, 7.5 per cent pentosanes, 1.8 per cent fat and resins, 8.7 per cent ash, 11.9 per cent moisture and 10.6 per cent of other nutrients (Tripetchkul et al., 2012). Because of its high C: $\mathrm{N}$ ratio (117: 1) (Noguera et al., 2000) and high lignin under natural conditions, its degradation and mineralization rates are very slow, preventing its direct use as organic manure. A study on coir pith, sewage sludge and compost incorporated equally in garden soil, silt and leaf mould showed that the incorporation of coir pith and compost lowered the $\mathrm{pH}$, maintained optimum EC and increased the organic carbon content improving nutrient uptake, yield and quality of marigold (Ahmad et al., 2012). Vermicompost is peat like material containing plant growth hormones, enzymes and plant available nutrients promoting crop growth and yield (Atiyeh et al., 2000). Dhaincha is an ideal quick growing and largely grown green manure crop. Its dry matter as a powder can also be used in the mixture of growing media as it is easily decomposable and supplier of organic carbon and nitrogen.

Fourier transform infrared (FT-IR) spectroscopy analysis is one of the most promising tool for characterizing heterogeneous organic matter by providing comprehensive information on the composition, properties and behaviour of the samples (Cuetoset al., 2010). In the present instrumental investigation, compost maturity and lignocellulosic organic substances predominant in coir pith, vermicompost and dhaincha powder were characterized based on the presence of functional groups by FT-IR spectroscopy.

\section{MATERIALS AND METHODS}

\section{Collection of substrate samples}

Raw coir pith blocks were obtained from an Agri-Clinic centre, Trichy, Tamil Nadu and soaked in water to loosen the pith fibers and sun-dried. Vermicompost was collected from vermicompost production centre, Department of Agronomy, Anbil Dharmalingam Agricultural College and Research Institute (ADAC\&RI), Trichy. The obtained vermicompost was thoroughly mixed and airdried. After drying, the samples were stored for analysis. Dhaincha (Sesbania aculeata) plants were harvested from the ADAC\&RI field, chopped into pieces, dried, ground as a powder in a flour mill and stored (Fig.1).

\section{Sample preparation for FT-IR analysis}

For the substrates viz., coir pith, vermicompost and dhaincha FT-IR spectra were obtained on FT-IR spectrometer (Thermo Scientific Nicolet iS10 model with DTGS KBr detector). In solid film (pellet) technique of sample preparation, $1 \mathrm{mg}$ of dried sample along with $100 \mathrm{mg}$ ) $\mathrm{KBr}$ (spectroscopy grade) was homogenized and compressed to pellet $(1 \mathrm{~mm}$ thickness, $13 \mathrm{~mm}$ diameter) using a hydraulic press (Fig. 2). Spectra were recorded over the frequency range of $4000-400 \mathrm{~cm}^{-1}$ with $4 \mathrm{~cm}^{-1}$ resolution averaging 32 scans and corrected against air as background. The spectra collected were finally processed using OMNIC Spectra software (Ravindran et al., 2013).

\section{RESULTS AND DISCUSSION}

\section{FT-IR spectroscopy analysis}

Solid-state spectroscopy is the most powerful tool which is used for examining the carbon composition of organic materials. One among them is FT-IR spectroscopy providing structural and compositional information on the functional groups present in the samples of organic substrates. Thus, this technique aids to confirm the products of decomposition containing several functional groups viz., polypeptides, polysaccharides, lignin, aliphatic, aromatic, carboxylic, phenolic groups existing in the substrates. In the present study, the spectra's different absorption peaks/ pattern and values showed the presence or absence of specific functional groups in the samples. In numerous FT-IR studies, relevant peaks attributing to specific functional groups/ and compounds were ascertained and these peaks were used as a guide for interpretation (Table 1).

\section{FT-IR spectra of coir pith}

Coir pith is an indigenously available agricultural organic solid byproduct, generated during the process of extraction of fibers from coconut husk. Before the last 20 years, coir pith was considered as a waste product of the extraction process and was dumped outside of coir 
Table 1. Assignment of typical infrared bands for grow media substrates from FT-IR spectra.

\begin{tabular}{|c|c|c|c|c|c|c|}
\hline \multirow{2}{*}{$\begin{array}{l}\text { S. } \\
\text { No. }\end{array}$} & \multirow{2}{*}{$\begin{array}{l}\text { Band position* } \\
\left(\mathrm{cm}^{-1}\right)\end{array}$} & \multirow{2}{*}{ Vibration* } & \multirow{2}{*}{$\begin{array}{l}\text { Functional group or } \\
\text { component }\end{array}$} & \multicolumn{3}{|c|}{$\begin{array}{c}\text { Wavelengths obtained for grow media } \\
\text { substrates from FTIR }\end{array}$} \\
\hline & & & & Coir pith & $\begin{array}{l}\text { Vermi } \\
\text { compost }\end{array}$ & Dhaincha \\
\hline 1. & $\begin{array}{l}3200-3500 \\
\text { (Broadband) }\end{array}$ & $\mathrm{O}-\mathrm{H}$ stretch & Alcohols and phenols & 3334.66 & 3291.75 & 3294.28 \\
\hline 2. & $\begin{array}{l}\text { 2925-2850 } \\
\text { (Peak) }\end{array}$ & $\mathrm{C}-\mathrm{H}$ stretch & $\begin{array}{l}\text { Aliphatic nature - Degradation } \\
\text { of cellulose, hemicelluloses, } \\
\text { lipids, fats }\end{array}$ & 2922.49 & 2918.01 & 2917.63 \\
\hline 3. & $\begin{array}{l}1738-1709 \\
\text { (Peak) }\end{array}$ & $\mathrm{C}=\mathrm{O}$ stretch & $\begin{array}{l}\text { Unconjugated ketone, carbonyl } \\
\text { and ester groups } \\
\text { Carbonyl group of hemicellu- }\end{array}$ & - & - & 1733.32 \\
\hline 4. & $1600-1650$ & $\mathrm{C}=\mathrm{O}$ stretch & $\begin{array}{l}\text { lose/lignin/ } \\
\text { amide groups }\end{array}$ & 1608.61 & 1634.71 & 1613.33 \\
\hline 5. & $1649-1521$ & $\begin{array}{l}\mathrm{C}=\mathrm{C} \text { aro- } \\
\text { matic struc- } \\
\text { ture }\end{array}$ & $\begin{array}{l}\text { Mineralization of protein, cellu- } \\
\text { lose, hemicelluloses. } \\
\text { Compost maturity }\end{array}$ & - & 1549.85 & - \\
\hline 5. & $1515-1510$ & $\begin{array}{l}\text { Aromatic } \\
C=C \text { stretch }\end{array}$ & Lignin & 1515.44 & 1514.87 & 1512.88 \\
\hline 6. & $1425-1410$ & COO`stretch & Carboxylic acids & 1423.10 & 1421.63 & 1422.27 \\
\hline 7. & $\begin{array}{l}1095-1030 \\
\text { (Sharp peak) }\end{array}$ & $\begin{array}{l}\text { C-O-C } \\
\text { stretch }\end{array}$ & Polysaccharides & 1031.68 & 1053.95 & 1031.74 \\
\hline 8. & $785-800$ & C-O stretch & Carbonate/and Silica & - & 789.69 & - \\
\hline
\end{tabular}

*Interpretive Source :Rout and Arulmozhiselvan (2019); Bhat et al. (2017); Jahan and Mun (2009)

fibre mills, causing large environmental pollution issues and serious health hazards of its own. When every 10 tons of coconut husks utilized for coir extraction, 1.6 ton of coir pith was obtained as a byproduct (Coir Board, International Coir Fair, 2016). During 2012, there was an accumulated stock of 10 million tons of coir pith in southern states (Reghuvaran and Ravindranath, 2014), while in all over India, only 10 lakh tons of coir pith are produced annually (Coir Board, India International Coir Fair, 2016). With the development of commercial horticulture and reduction in sphagnum peat availability, coco peat has become an internationally recognized ideal soil amendment and component of soilless container media for horticultural plants. In addition, coir pith also acts as an absorbent for eliminating pollutants from wastewater (Ali et al., 2012).

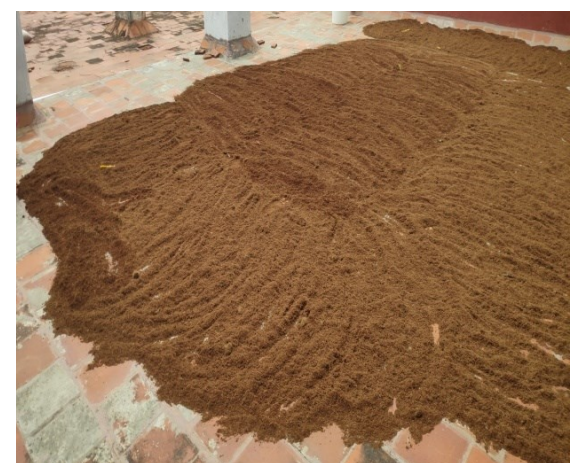

a) Sun drying of coir pith

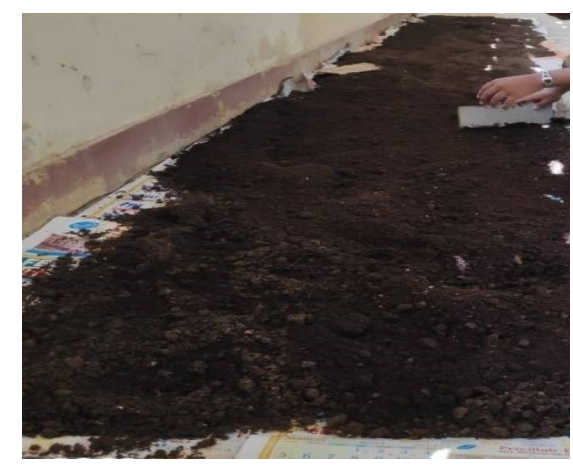

b) Air drying of vermicompost
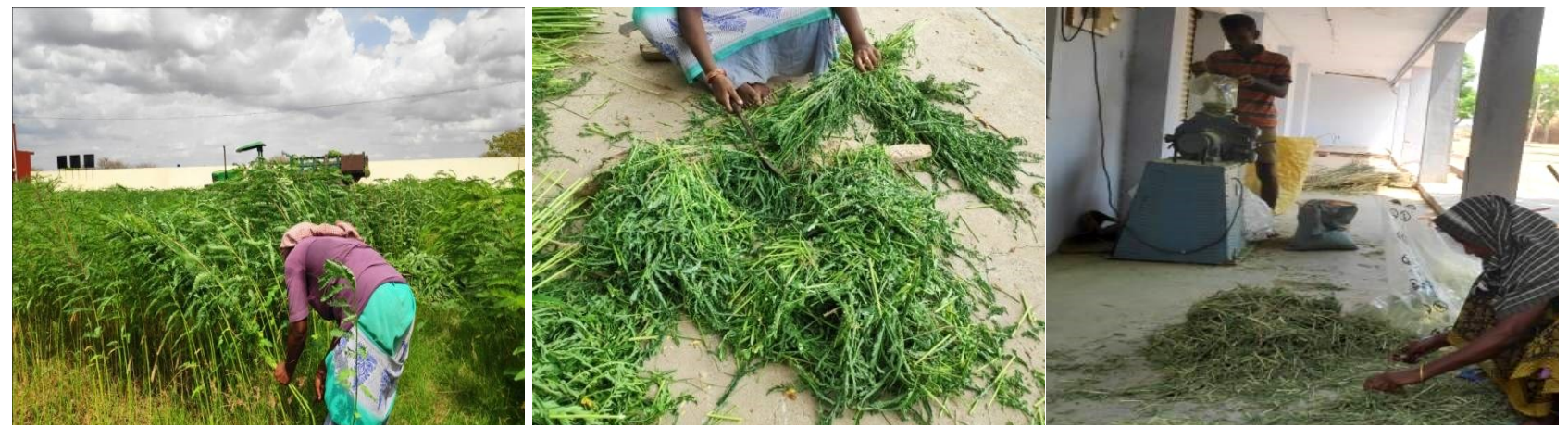

c) Dhaincha harvesting and powdering

Fig. 1. Processing of growing media substrates. 

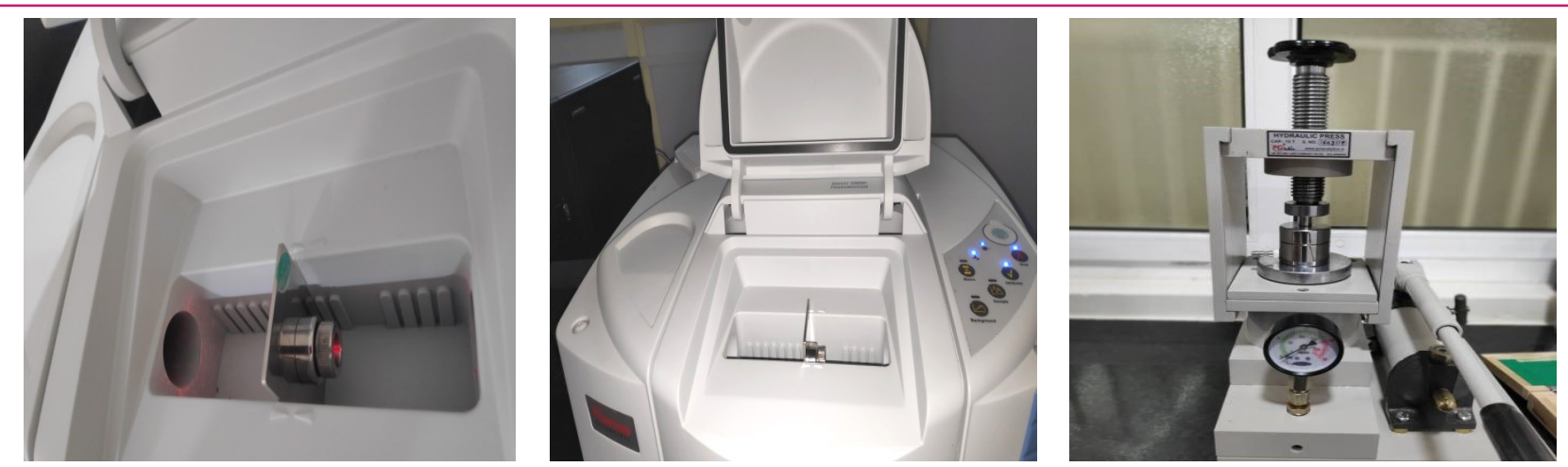

a) Thermo Scientific Nicolet iS10 model with DTGS KBr detector
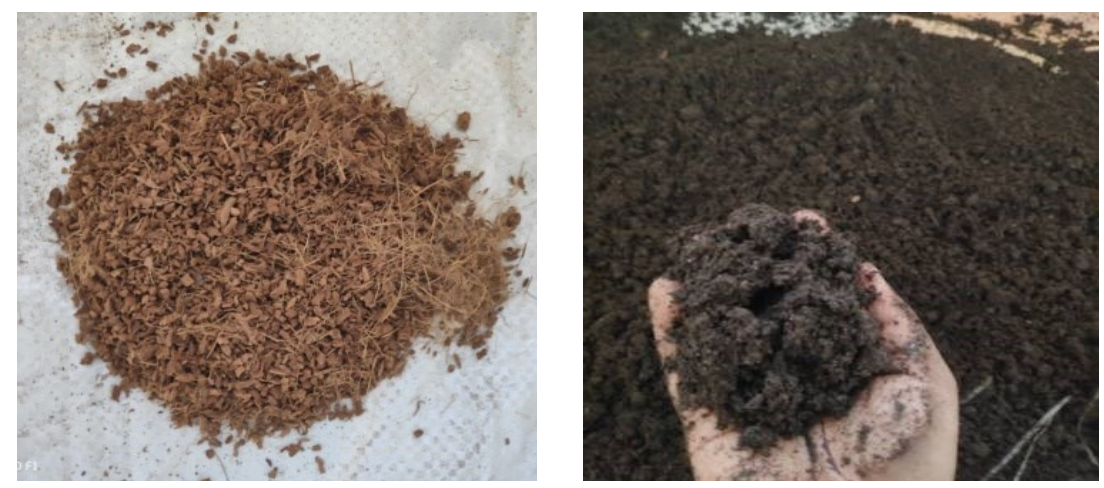

b) Hydraulic press
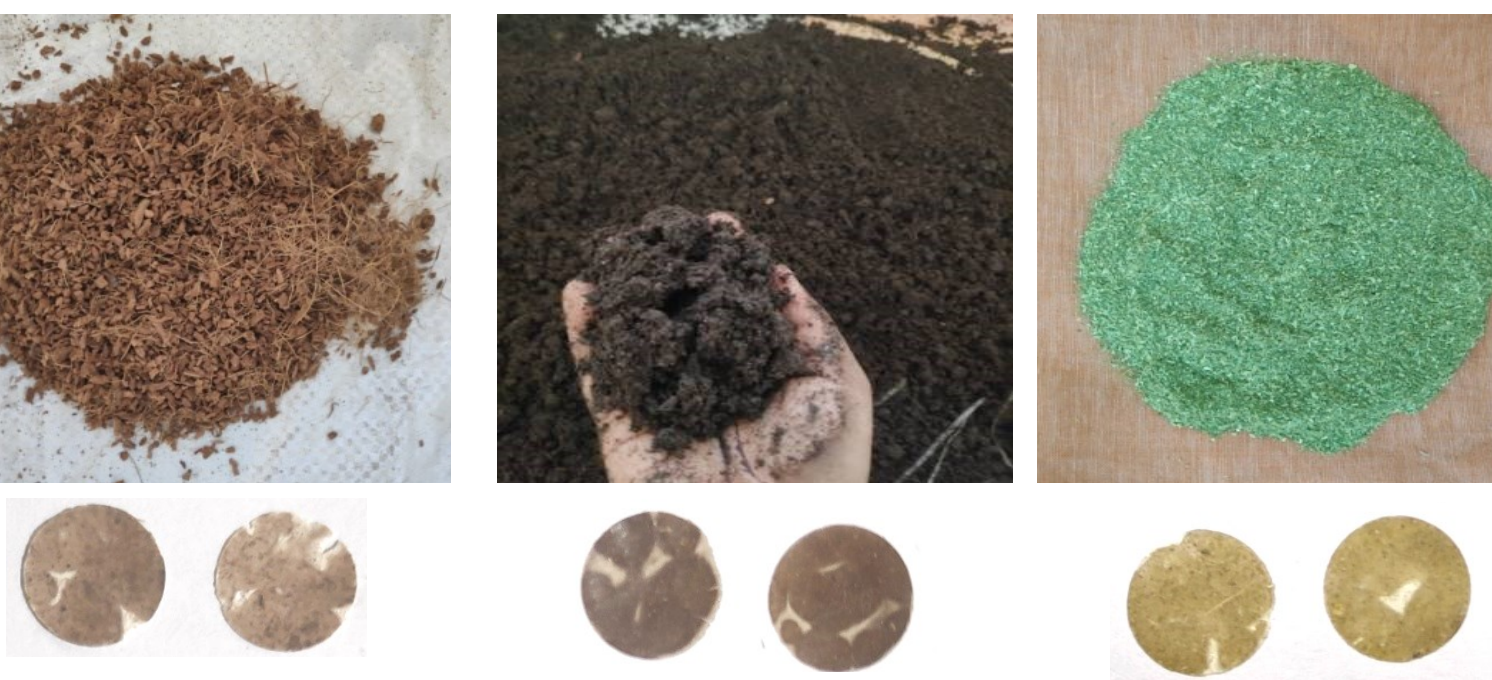

c) Substrate sample and their pellets

Fig. 2. Media pellet preparation by solid film technique in FT-IR.

The analysis of the FT-IR spectra of coir pith (Fig. 3) showed the presence of lignin, cellulose and hemicellulose, which are confirming the main characteristic of natural fibers. In general, the IR spectra with a broad, round band in between $3200-3600 \mathrm{~cm}^{-1}$ indicates axial deformation of the hydroxyl $(\mathrm{O}-\mathrm{H})$ group representing the presence of alcohols (Saberikhahet al., 2013). The exhibition of broadband at $3334.66 \mathrm{~cm}^{-1}$ might be indicative of the presence of stretch vibration of bonded hydroxyl groupsfrom cellulose structure (Anirudhanet al., 2007) on the coir dust. The weak band at $2922.49 \mathrm{~cm}$ ${ }^{1}$ would have been caused by $\mathrm{C}-\mathrm{H}$ stretch, which reflects the aliphatic nature of coir pith (Lazimet al., 2015). The peak at $1608.61 \mathrm{~cm}^{-1} \mathrm{might}$ be the reflection of the presence of carbonyl group $(\mathrm{C}=\mathrm{O})$ of hemicellulose in coir pith. Similar findings have been reported by Ammar et al. (2014); Rout and Arulmozhiselvan (2019).

The absorption peak at $1515.44 \mathrm{~cm}^{-1}$ might be the axial stretch of aromatic $\mathrm{C}=\mathrm{C}$ groups that ensures the presence of lignin, a prominent constituent of coir pith, as reported by Boeriuet al. (2004) and Lazimet al. (2015). The presence of lignin is a sign of a complex carbon backbone and a high degree of polymerisation, impeding resistance against degradation. The vibration at
$1423.01 \mathrm{~cm}^{-1}$ might be corresponding to the -COOantisymmetric stretching of carboxylic acids as per the reports of Bhat et al. (2017). The characteristic peak at $1370.27 \mathrm{~cm}^{-1}$ could be due to weak vibration of $\mathrm{OH}$ deformation of phenolic group, $\mathrm{CH}_{3}$ bending, or $\mathrm{C}-\mathrm{O}$ stretching. Similar findings are reported by Lailiet al. (2010) in humic acids present in coir pith.

All the substrates showed a sharp peak between 1095 and $1030 \mathrm{~cm}^{-1}$ attributable to -OCO- and -C-Ostretch in alcohols, esters and ethers, which would also show the presence of lactones and polysaccharides as stated by Davila-Rodriguez et al.(2009).

\section{FT-IR spectra of vermicompost}

Vermicompost comes as an excellent product since it is homogenous has desirable aesthetics, has minimal contamination levels, and tends to hold more nutrients over a longer period without adversely impacting the environment (Ndegwa and Thompson, 2000). Mineralization of organic matter and degradation of complex aromatics (lignin, polyphenols) into simpler compounds (carbohydrates, lipids) can be analyzed by FT-IR spectroscopy. This technique indicates the stages of compost maturity and stability of compounds of degradation present. Therefore, it appears as a promising technique 


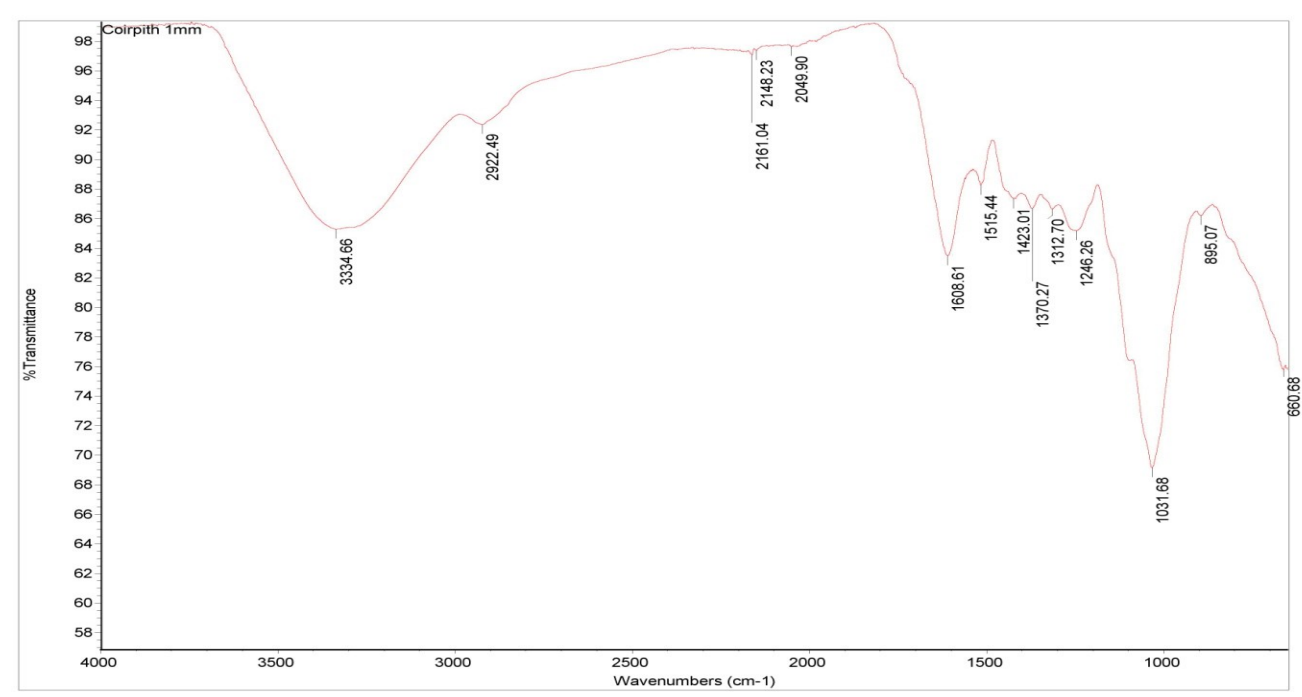

Fig. 3. FT-IR spectra of coir pith.

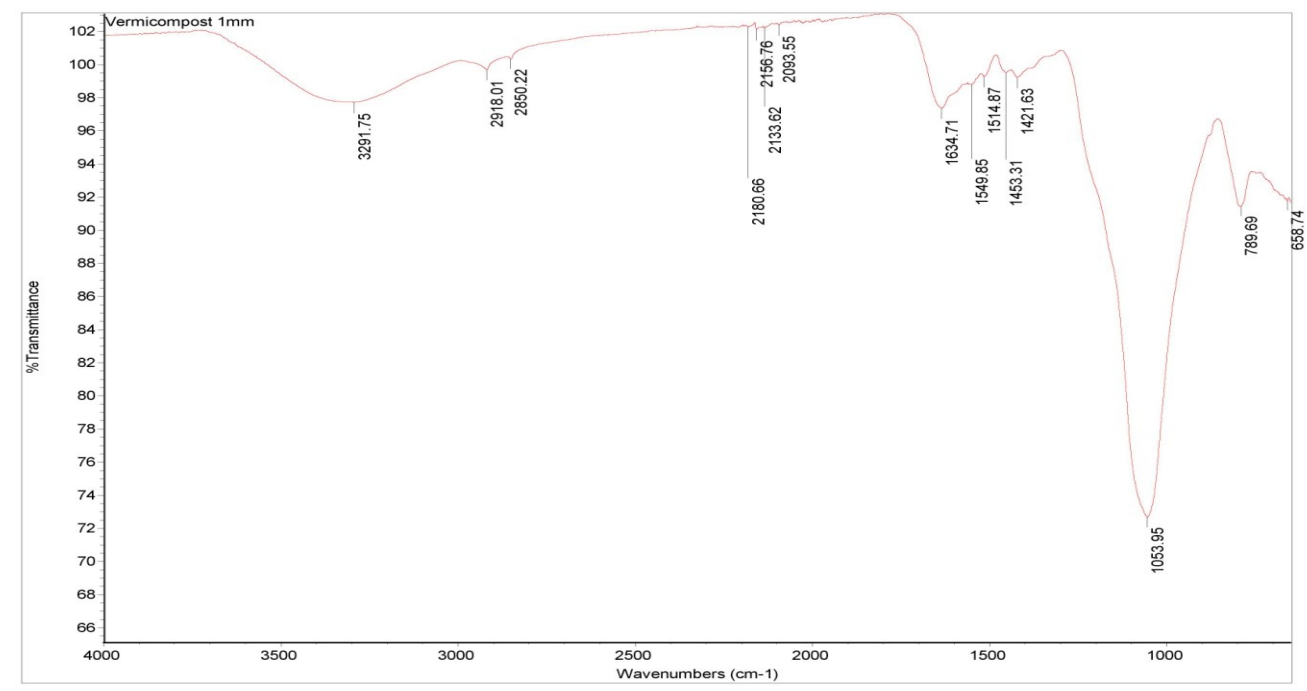

Fig. 4. FT-IR spectra of vermicompost.

to identify functional groups in compost in the process of vermicomposting. The spectral bands symbolize the presence or absence of certain functional groups aiding to predict the degradation or stabilization process at different stages.

In the recorded infrared spectra (Fig. 4), an intense wide band in between $3200-3500 \mathrm{~cm}^{-1}$ might indicate -OH stretching of alcohols and phenols group. Similar findings were reported by Pandey and Pitman (2003)in fungi; Simkovic et al. (2008) in soil organic matter; Amir et al. (2010) in humic acids and Hussain et al. (2016)in vermicompost. The decrease in intensity of band from 3291.75 to $2918.01 \mathrm{~cm}^{-1}$ would be the indication of the evidence of intense biodegradation ensuring compost maturity. Similar results were given by Ganguly and Chakraborty (2019).

The band at wave number $1634.71 \mathrm{~cm}^{-1}$ shows the existence of lignin. The peak value around $1549.85 \mathrm{~cm}^{-1}$ indicate $\mathrm{C}=\mathrm{C}$ aromatic structure formed during mineralization of protein, cellulose and hemicelluloses. This increase in the aromatic carbon is considered as an indicator of an increasing degree of organic matter humification associated with compost maturity and stability and their transformation to the highly humified substrate. These interpretations corroborate the reports of Huag et al. (2006) who have indicated an increase in polycondensed structures by detecting with FT-IR Spectra, and concluded that the mature compost derived from pig manure with saw dust contained more stable organic matter.

In another study, FT-IR spectra exhibited an increase in absorbance at $1453.31,1421.63 \mathrm{~cm}^{-1}$ and a strong increase at $1053.95 \mathrm{~cm}^{-1}$, also the appearance of new small peaks around 1634.71 and $1514.87 \mathrm{~cm}^{-1}$ which were mainly attributed to aromatic ethers from ligninlike structures. This confirms the decrease in aliphatic structures and the increase in more oxidized, polycondensed aromatic structures as reported by Ammar et al. (2014) in lignin samples, while vibration at 789.69 $\mathrm{cm}^{-1}$ might be the indication of $\mathrm{C}-\mathrm{O}$ stretch associated 


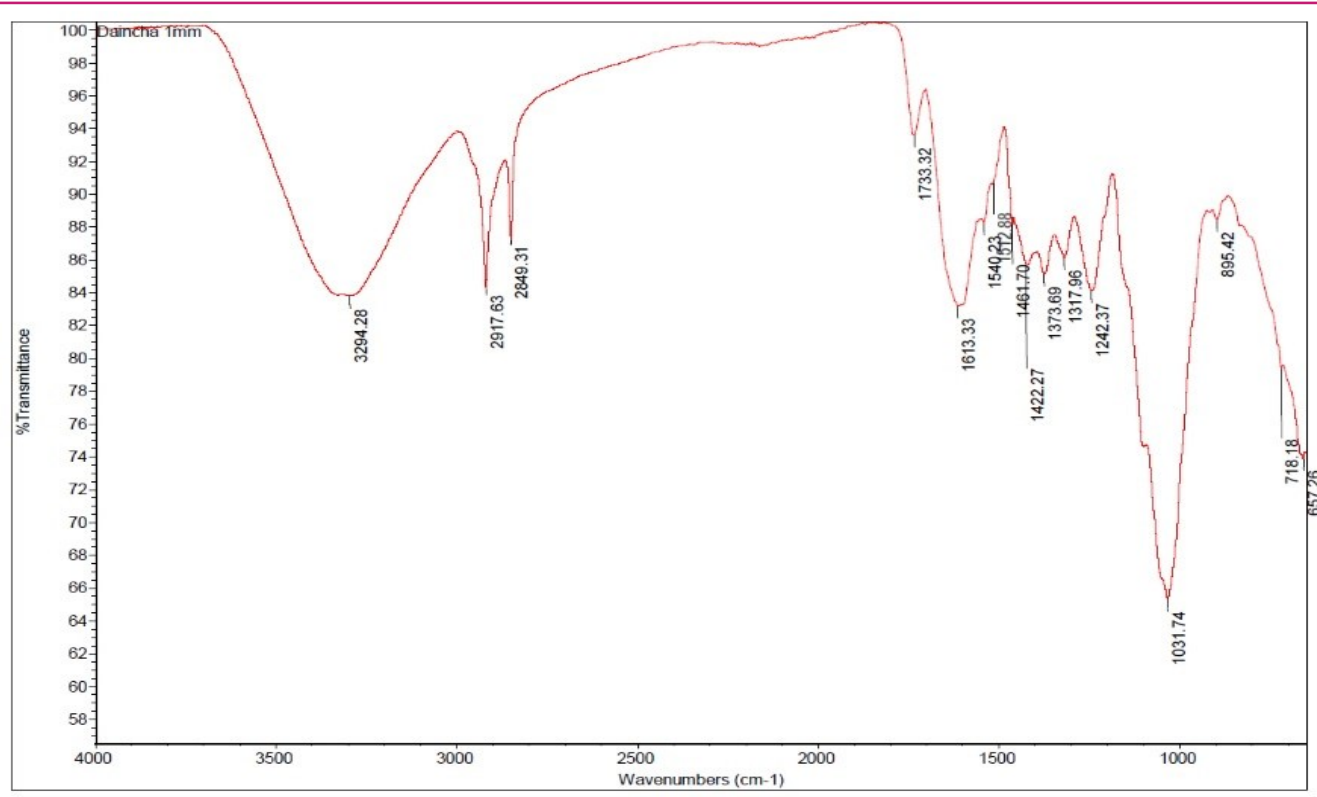

Fig. 5. FT-IR spectra of Dhaincha.

with carbonate/and silica as observed from the FTIR results of vermicomposts by Carrasquero-Duran and Flores (2009) and Ravindran et al. (2008).

\section{FT-IR spectra of dhaincha}

Green manure is an excellent natural source of nitrogen for cultivated crops. Dhaincha, a stem nodulating green manure crop,is widely available in many tropical countries of Asia and Africa and is considered the most promising of the green manure crops for wetland rice since it has high nitrogen fixing ability in standing water. The major use of the crop has been for fodder for livestock and green manure to improve soil fertility. FT-IR spectra were recorded for the dry matter of dhaincha, which was ground as a powder (Fig. 5) and based on the assignments made by Faix (1991) the spectral pattern can be interpreted as follows:

In the region between $3412-3460 \mathrm{~cm}^{-1}$, the absorbance at $3294.28 \mathrm{~cm}^{-1}$ correspond to $-\mathrm{OH}$ stretching vibrations of polysaccharides and amino groups. The peak value around $3000-2842 \mathrm{~cm}^{-1}$ have been assigned to $\mathrm{C}-\mathrm{H}$ stretch in methyl and methylene group of lignin extracted from different non-woods. In the present sample, such peaks were found at 2917.63 and 2849.31 $\mathrm{cm}^{-1}$.

The presence of vibration at $1738-1709 \mathrm{~cm}^{-1}$ would be due to $\mathrm{C}=\mathrm{O}$ stretch associated with an unconjugated ketone, carbonyl and ester groups. Such peak appeared at $1733.32 \mathrm{~cm}^{-1}$ for the present sample. The bands around 1610 and $1422 \mathrm{~cm}^{-1}$ depict the aromatic skeleton vibrations plus $\mathrm{C}=\mathrm{O}$ stretching and aromatic skeleton vibrations plus $\mathrm{CH}$ in plane deformation. The spectra showing signs of absorbance between 1505 and 1515 and $1460-1470 \mathrm{~cm}^{-1}$ can be associated with aromatic skeleton vibration and $\mathrm{C}-\mathrm{H}$ deformations (asymmetric in $-\mathrm{CH}_{3}$ and $-\mathrm{CH}_{2}$ of lignin) respectively. As per the reports of Jahan and Mun (2009), the sharp peak appearing at 1031.74 would be the indication of the aromatic $\mathrm{C}-\mathrm{H}$ in plane deformation plus $\mathrm{C}-\mathrm{O}$ deformation in primary alcohols plus $\mathrm{C}-\mathrm{H}$ stretching (unconjugated) of polysaccharides.

\section{Advantages and limitations}

FT-IR spectroscopy is used to study the substrates without any chemical treatment, which would cause unsuitable reactions. It is simple, quick, highly sensitive, informative for evaluation of the functional groups in organic substrates and environment friendly as it produces remarkably less waste. Solid, liquid, as well as gas can be analyzed with FT-IR spectroscopy. The disappearance or the appearance of a new band in the FT-IR spectra provides essential information about the organic matter evolution and its interaction with heavy metals. Organic and inorganic compounds can also be easily identified with the spectra obtained.

FT-IR spectroscopy is a single beam technique. It cannot detect atoms or monoatomic ions. It is impossible to measure the level of an element in a substance unless it is present as a part of a molecule whose spectrum can be detected (Bhat et al., 2017).

\section{Conclusion}

In the present study, FT-IR analysis in coir pith and dhaincha samples confirmed the occurrence of lignin, hemicellulose and cellulose, which are the main characteristics of natural fibers with high water-holding and cation exchange capacity. The presence of alcoholic and carboxylic groups would be indicative of stages of compost maturity and stability. It also showed the pres- 
ence of functional groups on their surfaces, which provide a conducive physical, chemical, and biological environment for crop growth. Therefore, these renewable and environmentally sustainable lignocellulosic organic materials, viz., coir pith, vermicompost and dhaincha could be recognized as ideal soilless substrates for preparing growth media for containerized crop production. Further, utilizing these organic materials paves the way for recycling organic wastes in an environmentally friendly manner. Therefore, an ideal soilless media while improving crop productivity can minimize the risks associated with soil-based cultivation.

\section{ACKNOWLEDGEMENTS}

The laboratory and instrumentation facility provided by the Centre of Excellence in sustaining Soil Health (COE -SSH), Anbil Dharmalingam College and Agricultural Institute, Trichy, for carrying out the sample analysis for the present study is duly acknowledged.

\section{Conflict of interest}

The authors declare that they have no conflict of interest.

\section{REFERENCES}

1. Ahmad, I., Ahmad, A., Ahmad, S., Amjad, A., Saleem, M. \& Akram, A. (2012). Effect of various agricultural substrates on biometric and qualitative characteristics of Ruscus hypophyllum. International Journal of Agriculture Biology, 14 (1), 116-120.

2. Ali, I., Asim,M. \& Khan,T.A. (2012). Low cost adsorbents for the removal of organic pollutants from wastewater. Journal of Environmental Management,113, 170 DOI: 10.1016/j.jenvman.2012.08.028.

3. Amir, S., Jouraiphy, A., Meddich, A., El Gharous, M., Winterton, P. \& Hafidi, M. (2010). Structural study of humic acids during composting of activated sludge-green waste: elemental analysis, FTIR and ${ }^{13}$ CNMR. Journal of Hazardous Materials, 177, 524-529.

4. Ammar, M., Khiari, R., Berrima, B., Belgacem, M.N. \&Elaloui,E. (2014). Isolation and characterization of lignin from Stipa tenacissima L. and Phoenix dactylifera. Cellulose Chemistry and Technology, 48, 255.

5. Anirudhan, T.S., \& Unnithan, M.R., (2007), Arsenic (V) removal from aqueous solutions using an anion exchanger from coconut coir pith and its recovery. Chemosphere, 66, 60-66.

6. Atiyeh, R.M., Dominguez, J., Subler,S. \& Edwards, C.A. (2000). Changes in biochemical properties of cow manure processed by earthworms (Eisenia andrei) and their effects on plant-growth. Pedobiology, 44, 709-724.

7. Barrett, G.E., Alexander, P.D., Robinson, J.S. \& Bragg, N.C. (2016). Achieving environmentally sustainable growing media for soilless plant cultivation systems - A review. Scientia Horticulturae, 212, 220-234. DOI: 10.1016/ j.scienta.2016.09.030.

8. Bhat, S.A., Jaswinder Singh \& Adarsh Pal Vig (2017).
Instrumental characterization of organic wastes for evaluation of vermicompost maturity. Journal of Analytical Science and Technology, 8, 2. DOI: 10.1186/s40543-017 -0112-2.

9. Boeriu, C.G., Bravo, D., Goselink, R. J. A. \& Van Dam, J. E. G. (2004). Characterization of structure-dependent functional properties of lignin with infrared spectroscopy. Industrial Crops and Products, 20(2), 205-218. DOI: 10.1016/j.indcrop.2004.04.022.

10. Carrasquero-Duran, A. \& Flores, I. (2009). Evaluation of lead (II) immobilization by a vermicompost using adsorption isotherms and IR spectroscopy. Bioresource Technology, 100(4), 1691-1694. DOI: 10.1016/j.biortec h.20 08.09.013.

11. Coir Board, India International Coir Fair (IICF). (2016). Coir pith wealth from waste - A reference, Coir Board, Kerala, Ministry of MSME, Government of India. p. 24. www.coirboard.gov.in/wp-content/uploads/2016/07/CoirPith.pdf

12. Contreras-Ramos, S.M., Alvarez-Bernal, D., TrujilloTapia, N. \& Dendooven, L. (2004). Composting of tannery effluent with cow manure and wheat straw. Bioresource Technology, 94(2), 223-228. DOI: 10.1016/j.biortech.20 03.12.001.

13. Cuetos, M.J., Gomez, X., Otero, M. \&Moran.,A. (2010). Anaerobic digestion of solid slaughterhouse waste: study of biological stabilization by Fourier Transform infrared spectroscopy and thermo gravimetry combined with mass spectroscopy. Biodegradation, 21, 543-556.

14. Davila-Rodriguez, J. L., Escobar-Barrios, V. A., Shirai, K. \& Rangel-Mendez, J. R.(2009). Synthesis of a chitinbased biocomposite for water treatment: Optimization for fluoride removal. Journal of Fluorine Chemistry,130(8), 718-726. DOI:10.1016/j.jluchem.2009.05.012.

15. Faix, O. (1991). Classification of lignins from different botanical origins by FTIR spectroscopy. Holzforschung, 45 (Suppl.), 21-27.

16. Ganguly, R.K. \& Chakraborty, S.K. (2019). Assessment of qualitative enrichment of organic paper mill wastes through vermicomposting: humification factor and time of maturity. Heliyon, 5(5), e01638. DOI: 10.1016/j.hel iyon.2019.e01638.

17. Gruda, N., Savvas, D., Colla, G. \& Rouphael, Y. (2018) Impacts of genetic material and current technologies on product quality of selected greenhouse vegetables - A review. European Journal of Horticultural Science, 83(5), 319-328. DOI: 10.17660/eJHS.2018/83.5.5.

18. Gruda, N., Gianquinto, G., Tüzel, Y., \& Savvas, D. (2016a). Culture soil-less In: Encyclopedia of Soil Sciences, $3^{\text {rd }}$ edn., R. Lal., ed. CRC Press, Taylor \& Francis Group, 533-537. DOI: 10.1081/E-ESS3-120053777.

19. Gruda, N., Caron, J., Prasad, M. \& Maher, M.J. (2016b). Growing media. In Encyclopedia of Soil Sciences, $3^{\text {rd }}$ edn., R. Lal., ed. CRC Press, Taylor \& Francis Group, 1053-1058. DOI: 10.1081/E-ESS3-120053784.

20. Gruda, N.,Qaryouti, M.M. \&Leonardi, C. (2013). Growing media In: Good Agricultural Practices for Greenhouse Vegetable Crops - Principles for Mediterranean Climate Areas. Food and Agriculture Organization of the United Nations (FAO), Rome, Italy. Plant Production and Protection Paper,217, 271-302.

21. Gruda, N. (2012). Current and future perspective of grow- 
ing media in Europe. Acta Horticulturae, 960, 37-43. DOI: 10.17660/ ActaHortic.2012.960.3.

22. Huag, G. F., Wu, Q.T., Wong, J. W.C. \&Nagar, B. B. (2006). Transformation of organic matter during composting of pig manure with saw dust. Bioresource Technology, 97, 1834-1842.

23. Hussain, N., Abbasi, T. \& Abbasi, S.A. (2016). Transformation of the pernicious and toxic weed parthenium into an organic fertilizer by vermicomposting. International Journal of Environmental Studies, 73, 731-745.

24. Jahan, M.S. \& Mun, S. P.(2009). Studies on the macromolecular components of nonwood available in Bangladesh. Industrial Crops and Products, 30, 344-350.

25. Laili, Z., Omar, M., Yasir, M. S., Ibrahim, M.Z., Yahaya, M.Y. \& Murshidi, J.A. (2010). Instrumental characterization of coir pith ByXRD, FTIR and SEM after radium adsorption from aqueous solution under the presence of humic acids. AIP Conference Proceedings, 1202, 193. DOI: 10.1063/1.3295597.

26. Lazim, Z.M., Tony Hadibarata, Mohd Hafiz Puteh \& Zulkifli Yusop. (2015). Adsorption Characteristics of Bisphenol A onto Low-Cost Modified Phyto-Waste Material in Aqueous Solution. Water, Air, and Soil Pollution, 226, 34. DOI: 10.1007/s11270-015-2318-5.

27. Ndegwa, P.M. \&Thompson, S.A. (2000). Effects of C-to-N ratio on vermicomposting of biosolids. Bioresource Technology, 75, 7-12.

28. Noguera, P., Abad, M., Noguera, V., Puchades, R. \&Maquieira, A. (2000). Coconut coir waste, a new and viable ecologically-friendly peat substitute. Acta Horticulturae, 517, 279-286.

29. Pandey, K. \& Pitman, A. (2003). FTIR studies of the changes in wood chemistry following decay by brown-rot and white-rot fungi. International Biodeterioration and Biodegradation, 52(3),151-160. DOI: 10.1016/s0964-830 5(03)00052-0.

30. Papadopoulos, A. P., Bar-Tal, A., Silber, A., Saha, U. K. \&Raviv, M. (2008). In "Soilless Culture: Theory and Practice", edited by M. Raviv and J. H. Lieth, Academic Press, San Diego, USA, 505. https://www.elsevier.com/ books/soilless-culturetheory-and-practice/raviv/978-0-44452975-6.

31. Rout, P.P.\& Arulmozhiselvan, K.(2019). Investigating the suitability of pressmud and coir pith for use as soilless substrate by SEM, XRF, UV-VIS and FTIR spectroscopy techniques. Cellulose Chemistry and Technology, 53(5-6), 599-607.
32. Ravindran, B., Sravani, R., Mandal, A.B., ContrerasRamos, S.M. \& Sekaran, G. (2013). Instrumental evidence for biodegradation of tannery waste during vermicomposting process using Eudrilus eugeniae. Journal of Thermal Analysis and Calorimetry, 111, 1675-84.

33. Ravindran, B., Dinesh, S. L., John Kennedy, L. \& Sekaran, G. (2008). Vermicomposting of solid waste generated from leather industries using epigeic earthworm Eisenia fetida. Applied Biochemistry and Biotechnology, 151(23), 480-484.DOI:10.1007/s12010-008-8222-3.

34. Raviv, M. (2013). Composts in growing media: what's new and what's next? Acta Horticulturae, 982, 39-52. DOI: 10.17660/actahortic.2013.982.3.

35. Reghuvaran, A. \& Ravindranath, A.D. (2014). Use of coir pith compost as an effective cultivating media for ornamental, medicinal and vegetable plants. International Journal of Biology, Pharmacy and Allied Sciences,3, 88 - 97.

36. Saberikhah, E., Mohammadi-Rovshandeh, J. \& Mamaghani, M. (2013). Spectroscopic comparison of organosolvlignins isolated from wheat straw. Cellulose Chemistry and Technology, 47, 410.

37. Savvas, D. \& Gruda, N.(2018). Application of soilless culture technologies in the modern greenhouse industry A review. European Journal of Horticultural Science, 83 (5), 280-293.DOI: 10.17660/eJHS.2018/83.5.2.

38. Savvas, D. (2003). Hydroponics: A modern technology supporting the application of integrated crop management in greenhouse. Journal of Food, Agriculture and Environment, 1,80-86.

39. Schmilewski., G. (2009). Growing medium constituents used in the EU. Acta Horticulturae, 819, 33.DOI: 10.17660/ActaHortic.2009.819.3.

40. Simkovic, I., Dlapa, P.,Doerr, S.H., Mataix-Sol-Era,J. \&Sasinkova, V. (2008). Thermal destruction of soil water repellency and associated changes to soil organic matters as observed by FTIR spectroscopy. Catena, 74(3),205211. DOI: 10.1016/j.catena.2008.03.003.

41. Tripetchkul, S., Pundee, K., Koonsrisuk, S. \& Akeprathumchai, S. (2012). Co-composting of coir pith and cow manure: initial $\mathrm{C} / \mathrm{N}$ ratio vs physico-chemical changes. International Journal of recycling organic waste in agriculture,1(1), 15. DOI: 10.1186/2251-7715-1-15.

42. Vaughn, S.F., Deppe, N.A., Palmquist, D.E. \&Berhow, M.A. (2011). Extracted sweet corn tassels as a renewable alternative to peat in greenhouse substrates. Industrial crops and products, 33(2), 514-517. DOI:10.1016/j.indcr op.2010.10.034. 